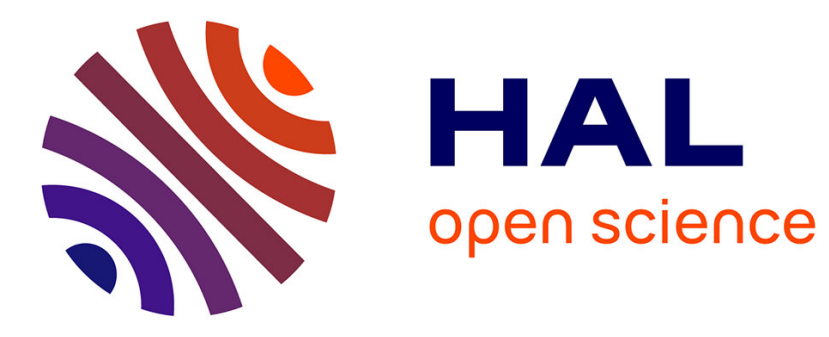

\title{
Bromine speciation in hydrous silicate melts at high pressure
}

Benjamin Cochain, Chrystèle Sanloup, C de Grouchy, C Crépisson, Hélène Bureau, C Leroy, I Kantor, T Irifune

\section{- To cite this version:}

Benjamin Cochain, Chrystèle Sanloup, C de Grouchy, C Crépisson, Hélène Bureau, et al.. Bromine speciation in hydrous silicate melts at high pressure. Chemical Geology, 2015, 404, pp.18-26. 10.1016/j.chemgeo.2015.03.015 . hal-01136078

\section{HAL Id: hal-01136078 https://hal.sorbonne-universite.fr/hal-01136078}

Submitted on 26 Mar 2015

HAL is a multi-disciplinary open access archive for the deposit and dissemination of scientific research documents, whether they are published or not. The documents may come from teaching and research institutions in France or abroad, or from public or private research centers.
L'archive ouverte pluridisciplinaire HAL, est destinée au dépôt et à la diffusion de documents scientifiques de niveau recherche, publiés ou non, émanant des établissements d'enseignement et de recherche français ou étrangers, des laboratoires publics ou privés. 


\title{
Bromine speciation in hydrous silicate melts at high pressure
}

\author{
B. Cochain ${ }^{1,2}$, C. Sanloup ${ }^{1,2}$, C. de Grouchy ${ }^{1}$,

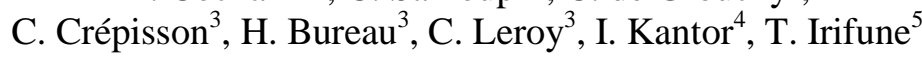

1) Scottish Universities Physics Alliance (SUPA), and Centre for Science at Extreme Conditions, School of Physics and Astronomy, University of Edinburgh, Edinburgh, EH9 3JZ, UK

2) Sorbonne Universités - UPMC Univ, Paris 06, UMR 7193, ISTeP, F-75005 Paris, France

3) Institut de Minéralogie, de Physique des Matériaux, et de Cosmochimie (IMPMC) Sorbonne Universités UPMC Univ Paris 06, UMR CNRS 7590, Muséum National d'Histoire Naturelle, IRD UMR 206, 4 Place Jussieu, F-75005 Paris, France

4) European Synchrotron Radiation Facility, 71, Avenue des Martyrs, Grenoble, France

5) GRC, Ehime University, Ehime, Japan.

\begin{abstract}
Br speciation in hydrous silicate melts at high pressure has been investigated up to 7.6 GPa using Xray Absorption Spectroscopy (XAS) at the Br K-edge in a Paris-Edinburgh press. Br in silicate melts is surrounded by an average of 6 Na cations, a number slightly increasing with pressure (5.8 to 6.6), with a Br-Na distance increasing from 3.49 to $3.72 \AA$. Two oxygens, either from a water, an - $\mathrm{OH}$ molecule or from the tetrahedral silicate network, with an average Br-O distance of $1.80 \AA$, form the closest coordination shell around $\mathrm{Br}$ ions. The persistence of an alkali shell around $\mathrm{Br}$, in a structure similar to crystalline $\mathrm{NaBr}$, throughout the pressure range investigated shows that $\mathrm{Br}$ can be retained in the melt structure at relatively high pressure and supports the idea of its deep recycling. Finally, our results confirm that $\mathrm{Br}$ could be efficiently degassed with water at low pressures and that $\mathrm{Br}$ may also have been efficiently degassed along with water during the early stages of an oxidized magma ocean.
\end{abstract}




\section{Introduction}

The halogens (fluorine, chlorine, bromine and to a lesser extent iodine) influence the properties of silicate melts and play an important role in a range of magmatic and hydrothermal processes, from the evolution of magmatic systems to the transport of metals in fluids and the environmental impact of atmospheric emissions during degassing processes (e.g., Aiuppa et al., 2009; Baasner et al., 2013; Chevychelov et al., 2008; Edmonds et al., 2009; Pyle and Mather, 2009). In order to predict the physical and chemical properties of silicate melts, the fluids that they exsolve, and the glasses that they form, a detailed knowledge of the solubility and speciation of halogens in silicate melts at relevant conditions of pressure and temperature is essential. Most previous experimental studies have focussed on the determination of their solubility, partitioning behaviour or diffusion at pressures relevant for degassing processes $(P<0.3 \mathrm{GPa}$ ) (Aletti et al., 2007; Baker and BalconeBoissard, 2009; Bureau et al., 2000; Bureau and Métrich, 2003, Signorelli and Caroll 2002; Webster, 1992). In a more recent investigation conducted at pressures of up to $1.7 \mathrm{GPa}$, Bureau et al., (2010) suggested that the Br cycle in subduction zones is divided in two parts: one superficial cycle, with $\mathrm{Br}$ being returned to the atmosphere via volcanism, and another deeper cycle, with $\mathrm{Br}$ being recycled back to the mantle via silicate melts. This raises the question of the $\mathrm{Br}$ local environment in high-pressure silicate melts as a function of pressure, which is currently virtually unknown. Knowledge of the local structure is particularly important for activity-composition models, which are used to calculate the effects of mixing on the thermodynamic properties of a system. Experimental measurements are therefore needed to constrain the local structure around the halogens in order to further quantify their chemical behaviour (solubility, partitioning behaviour and diffusion) in the subducting slab, mantle wedge and Earth's mantle. In addition, such measurements will ultimately help to model halogen mobilization, transport and degassing in subduction zones or during the degassing of the magma ocean. 
In this context, X-ray absorption spectroscopy (XAS), and more particularly extended X-ray absorption fine structure (EXAFS) spectroscopy can play an important role as it is extremely sensitive to the short-range structure around selected atomic sites in both solid and liquid phases. Indeed, in situ XAS measurements have previously been performed in hydrothermal diamond-anvil cells (HDAC) or autoclaves to characterize the speciation of diverse elements in geologically relevant environments at pressures of up to 2.4 GPa (Louvel, 2011; Louvel et al. 2012; Mayanovic et al., 2013; Testemale et al., 2009). The preliminary in situ XAS work of Louvel (2011) in HDAC on $\mathrm{Br}$ speciation in aqueous fluids, hydrous haplogranitic and sodium disilicate melts at up to 2.2 GPa has shown that water molecules in the coordination shell of $\mathrm{Br}$ in the fluids are gradually replaced by $\mathrm{Na}$ ions as the amount of dissolved alkali silicates in the fluid increases. In the present work, we investigated the Br speciation in a hydrous alkali silicic melt at high pressure using XAS at the $\mathrm{Br} \mathrm{K}$-edge and a Paris-Edinburgh press. Here, the use of the Paris-Edinburgh press has enabled us to record high-quality data with stable experimental conditions at higher pressures and temperatures relevant to subduction zones and the upper mantle. We therefore focussed our study on the speciation of $\mathrm{Br}$ in a hydrous silicic melt up to $7.6 \mathrm{GPa}$ and $1400{ }^{\circ} \mathrm{C}$. XAS (EXAFS and XANES) analysis were conducted on the parent $\mathrm{Br}$ bearing glass at ambient conditions, on the melt at 2.1, 3.4 and $7.6 \mathrm{GPa}$ at $1400 \pm 70{ }^{\circ} \mathrm{C}$, and on the resulting high-pressure quenched glasses. Six crystalline standards $\left(\mathrm{CaBr}_{2}, \mathrm{FeBr}_{2}, \mathrm{NaBr}, \mathrm{KBr}, \mathrm{KBrO}_{3}, \mathrm{NaBrO}_{3}\right)$ were measured to facilitate the modelling of the possible $\mathrm{Br}$ valences and chemical environments that may be present in the investigated melts and glasses. 


\section{Materials and Methods}

\subsection{Generation of high-pressure high-temperature conditions}

For the in situ measurements, high pressure-high temperature (high $P-T$ ) conditions of up to 7.6 $\mathrm{GPa}$ and $1400{ }^{\circ} \mathrm{C}$ were generated using a Paris-Edinburgh press. We used a modified cell assembly calibrated by Van Kan Parker et al. (2010), consisting of a 7/2.4 mm boron epoxy gasket, a graphite heater and an hBN pressure transmitting medium. We used nano-polycrystalline diamond (NPD) capsules synthesized at Geodynamics Research Center, Ehime University, Matsuyama, Japan (Irifune et al., 2003) instead of single crystal diamond or polycrystalline diamond capsules in order to eliminate the serious interference of the diamond Bragg peaks in the EXAFS spectra. Pt-Rh5\% lids were also inserted on either side of the nano-polycrystalline diamond capsule to prevent the loss of volatiles. The NPD cylinder $(1.5 \mathrm{~mm}$ in height and $0.75 \mathrm{~mm}$ inner diameter $)$ and Pt-Rh5\% lids were enclosed between two hBN caps on both ends acting as $P$-transmitting media. High $T$ was achieved by resistive heating through the graphite heater. A Pt foil was inserted between the diamond capsule and the graphite heater as a pressure marker. Pressure transmission to the sample inside the rigid nano-polycrystalline diamond capsule is fully achieved for temperature above $1000{ }^{\circ} \mathrm{C}$ (Van Kan Parker et al., 2010). Experiments were conducted by cold compression of the sample to a given pressure, followed by gradual heating to $1400{ }^{\circ} \mathrm{C}$ at constant oil pressure. The temperature was determined from previous calibration measurements of the cell-assembly (Van Kan Parker et al., 2010) and the pressure was derived from the cell volume of Pt. Estimated error bars are $\pm 0.25 \mathrm{GPa}$ on $P$, and $\pm 70{ }^{\circ} \mathrm{C}$ on $T$. Before recording the EXAFS spectra, the molten state of the sample was assessed by the disappearance of crystalline Bragg peaks in the diffraction patterns recorded on a MAR detector. X-ray radiographic images of the sample were systematically recorded before and after collection of XAS data to check for homogeneity/ heterogeneity of the sample and the lack of crystallization. 


\subsection{Samples and characterization of materials}

Silicic andesite samples from recent eruptions of Mt. Pelée (Martel et al., 1998) were first melted at $1450^{\circ} \mathrm{C}$ under atmospheric conditions for one hour before quenching to a glass in distilled water. The glass was ground in an agate mortar under ethanol and re-melted to ensure chemical homogeneity. It was then doped with $4 \mathrm{wt} \% \mathrm{NaBr}$ and $4 \mathrm{wt} \% \mathrm{H}_{2} \mathrm{O}$ in a internally heated pressure vessel pressurized with an $\mathrm{Ar}-\mathrm{H}_{2}$ gas mixture, holding for forty-two hours at $1250^{\circ} \mathrm{C}$ and $0.2 \mathrm{GPa}$ thus ensuring the presence of iron in its reduced form, $\mathrm{Fe}^{2+}$, in the parent glass. The composition of the parent glass and the quenched products recovered from the 2.1 and $3.4 \mathrm{GPa}$ runs, as specified in Table 1, were determined with a CAMECA SX100 electron microprobe at the EMMAC centre (The Edinburgh Materials and Micro-Analysis Centre), University of Edinburgh. It was not possible to retrieve and analyse the quenched sample from the $7.6 \mathrm{GPa}$ run as a blowout occurred before quenching. The microprobe analyses were performed under "soft" operating conditions, in order to avoid any loss of $\mathrm{Na}$ and volatiles, with a $15 \mathrm{kV}$ accelerating voltage, a defocused beam of $10 \mu \mathrm{m}$ and a current of $15 \mathrm{nA}$. We note that the parent glass and the run products have similar chemical compositions, given the analytical uncertainties, with the exception of the lack of iron in the run products, a result of the reaction between the $\mathrm{Fe}^{2+}$ present in the parent glass with the $\mathrm{Pt}-\mathrm{Rh} 5 \%$ lids of the Paris-Edinburgh cell assemblies. The electron microprobe analysis of $\mathrm{Br}$ is hindered by the high ionization potential for the $\mathrm{K}$-lines of $\mathrm{Br}$, resulting in low count rates and the overlapping of the $\mathrm{L}$ - lines of $\mathrm{Br}$ and the $\mathrm{K}$-lines of $\mathrm{Al}$. The $\mathrm{Br}$ concentration of the parent and glasses quenched from high pressure was instead determined by Proton-induced X-ray emission (PIXE) analyses performed using a nuclear microprobe (LEEL, CEA/DSM/IRAMIS/SIS2M, CEA Saclay, France), using $3 \times 3 \mu \mathrm{m}^{2}$ incident beams of protons at 3.2 and $2.5 \mathrm{MeV}$. $\mathrm{Br}$ was detected based on the $\mathrm{K} \alpha$ and $\mathrm{K} \beta$ X-rays (11.92 and $13.29 \mathrm{KeV}$ respectively). The details of the procedure are described in (Bureau et al., 2010). The PIXE analysis yielded a Br concentration of $2.20 \pm 0.13$ wt $\%$ for the starting glass, which is identical to the $\mathrm{Br}$ concentration determined by electron microprobe analysis 
within analytical uncertainties (see Table 1). The glasses quenched from high pressure were also studied by Scanning Electron Microscopy (SEM) with a Zeiss Ultra 55 field emission scanning electron microscope (SEM) with a working distance of $3 \pm 0.2 \mathrm{~mm}$ and an acceleration voltage of $15 \mathrm{keV}$ at the Institut de Minéralogie, de Physique des Matériaux et de Cosmochimie (IMPMC), Sorbonne Universités, Paris, France (Fig. 1a). A few sanidine crystals are noticeable in the vicinity of the capsule's walls, but these do not hinder the EXAFS analysis as the EXAFS spectra are representative of the sample in the centre of the capsule. The water content of the samples was determined by Raman spectroscopy measurements (le Losq et al., 2010) and by Elastic Recoil Detection Analysis (ERDA) (Khodja et al., 2001; Bureau et al., 2009). Raman spectra were acquired at the IMPMC using the 1500 grooves $/ \mathrm{mm}$ grating of the spectrometer and a $514 \mathrm{~nm}$ wavelength laser and are shown on Fig. 1b. ERDA measurements were carried out using a Van de Graff accelerator (LEEL, CEA/DSM/IRAMIS/SIS2M, CEA Saclay, France) producing a $3 \mathrm{MeV}$ ${ }^{4} \mathrm{He}^{+}$micro-beam with a final incident beam size of approximately $16 \times 4 \mu \mathrm{m}^{2}$ (horizontal $\times$ vertical).

\subsection{XAS data acquisition}

XAS measurements at ambient and high $P-T$ conditions were performed in transmission mode across the Br-K edge (13.47 keV) on the BM23 beamline at the European Synchrotron Radiation Facility (ESRF - Grenoble, France). Details of the beamline layout are reported elsewhere (Filipponi et al., 2000). The storage ring was operating in the 16-bunch mode with an average current of $200 \mathrm{~mA}$. X-rays were generated using a bending magnet, and monochromatised with a double-crystal, fixed exit $\mathrm{Si}(111)$ monochromator. The beamsize was $0.1 \times 0.5 \mathrm{~mm}^{2}$. The energy of the EXAFS spectra was calibrated using a pellet of $\mathrm{NaBr}$ powder (Alfa Aesar) and no significant drift of the energy was observed for the duration of the measurements. EXAFS spectra of the Brbearing reference compounds listed in Table $2\left(\mathrm{NaBrO}_{3}, \mathrm{KBrO}_{3}, \mathrm{NaBr}, \mathrm{KBr}, \mathrm{CaBr}_{2}\right.$ and $\left.\mathrm{FeBr}_{2}\right)$, the 
Br-doped parent glasses and the glasses quenched from high-pressure (Table 3) were recorded in transmission from 13.30 to $14.30 \mathrm{keV}$ with a total scan time of about 20 minutes. For the in situ measurements (Table 3), the spectra were recorded in transmission between 13.30 and $13.71 \mathrm{keV}$ with a total scan time of about 15 minutes.

\subsection{EXAFS data analysis}

The extended X-ray absorption fine structure (EXAFS) signal $(\chi)$ was first extracted using the ATHENA and ARTEMIS packages based on the IFEFFIT program (Ravel and Newville, 2005). An average of 3 to 5 EXAFS spectra were first normalized to the absorption edge height. We used an automated background subtraction method (AUTOBK) developed by Newville et al. (Newville, 2001) and implemented in the ATHENA software. This method systematizes the k-space placement of the cubic spline function that is used to approximate the post-edge absorbance from an isolated atom. The placement of the spline is chosen so as to minimize the R-space features at distances that are well below the first atom-atom contact distance. This minimum $\mathrm{R}$-space distance, $\mathrm{R}_{\mathrm{bkg}}$, was chosen as 1.4 $\AA$ (Wallen et al. 1997; Evans et al., 2007, 2009). The intensity of the jump was normalised to 1 and the position of the edge, $E_{0}$, was calculated as the first maximum of the first derivative of the absorption spectra $(\sim 13.478 \mathrm{keV})$. EXAFS interference functions, $\chi(k)$, multiplied by $\mathrm{k}^{2}$ to increase the signal at high $\mathrm{k}$ values, were exported into ARTEMIS. These data were Fourier transformed via a Hanning window and fit to the EXAFS equation (Newville, 2001) over a variable k-range depending on the sample analysed, the experimental conditions and the signal to noise ratio of the EXAFS spectra. A k-range of 2.25-10 $\AA^{-1}$ was used for the crystalline references, except for the $\mathrm{NaBr}$ and $\mathrm{FeBr}_{2}$ model compounds for which a k-range of $2.25-8 \AA^{-1}$ was used due to the lower quality of the data at high energy. For the glasses at ambient and the melts at high $P-T$ conditions, we used a k-range of 2-7 $\AA^{-1}$, except for the glass quenched from high pressure recovered from the 2.1 GPa run for which a k-range of 2-6.5 $\AA^{-1}$ was used. The shorter k-range used for the fitting of 
the glasses and melts EXAFS spectra ensures that all the different contributions to the Fourier transforms arise from neighbouring atoms and are not artefacts from the data treatment. For all compositions, the fit parameters included the number of neighbouring atoms, $N$, around the central $\mathrm{Br}$ atom, the average distance, $d$, to the central $\mathrm{Br}$ atom, the Debye-Waller factor, $\sigma^{2}$, characterizing the degree of disorder present in the signal, the amplitude reduction factor, $S_{0}{ }^{2}$, and the difference between the initial model nearest neighbour distance and the real distance, $\Delta E_{0}$. All the fits were conducted with a k-weighting of 1 and 2 to decrease correlations between $N$ and $\sigma^{2}$ (Pokrovski et al., 2013). The fits were also performed assuming that the theoretical backscattering amplitude and phase shift functions could have absorber-scatterer distances that differ from the original model by a distinct number of Angstroms. The Debye-Waller factor, $\sigma^{2}$, was fitted for all experimental spectra and set to the best fitted values for each spectrum to minimize errors and correlations between the derived structural parameters. The fitted values of $\Delta E_{0}$ never exceed $6 \mathrm{eV}$, confirming the validity of the fitting procedure. Finally, the third order anharmonic cumulant-expansion fitting parameter, $\sigma^{3}$, which is a measure of the asymmetry in the signal disorder, was included in the fitting of the melts EXAFS spectra in order to partially compensate for the structural disorder due to the high $P-T$ conditions. The goodness of the fits is expressed by the R-factor, which is a sum-of-squares of the fractional misfit between the model and EXAFS data (Newville, 2001).

\section{Spectroscopic results}

\subsection{Reference materials}

Fig. 2 shows the normalized XANES spectra, $\mathrm{k}^{2}$-weighted EXAFS oscillations, $k^{2} \chi(k)$, and their Fourier transforms collected for the crystalline reference materials used to fingerprint the local structural environment of Br. Quantitative analyses of the XANES data were not performed in this study and only a qualitative description is presented. The XANES spectra absorption edge is found 
at $E_{0}=13478 \pm 0.5 \mathrm{eV}$ for the bromide reference compounds and $E_{0}=13480 \pm 0.5 \mathrm{eV}$ for the bromate oxides reflecting a change in $\mathrm{Br}$ formal charge from $\mathrm{Br}^{2-}\left(\mathrm{CaBr}_{2}, \mathrm{FeBr}_{2}\right)$ and $\mathrm{Br}^{-}(\mathrm{NaBr}$, $\mathrm{KBr}$ ) to $\mathrm{Br}^{5+}$ for the oxides. All the XANES spectra present a relatively broad white line that peaks at a $13482 \pm 0.5$ and $13484 \pm 0.5 \mathrm{eV}$ for the bromides and the bromate oxides respectively. They also exhibit noticeable differences in the shape of the absorption edge crest relative to the $\mathrm{Br}$ structural environment. The intensity of the absorption edge is greater for the $\mathrm{Br}$ oxides $\mathrm{NaBrO}_{3}$ and $\mathrm{KBrO}_{3}$, while it is smaller for the bromide compounds with a minimum for $\mathrm{NaBr}$ bromide. The absorption edge crest of the KBr XANES spectrum splits into two components, as previously observed by Soldatov et al. (1993) and Freund et al. (1991). These differences in the XANES spectra point to distinct structural environments of $\mathrm{Br}$, which are also reflected in the corresponding EXAFS oscillations (Fig. 2b) where the frequency of the oscillations varies with the $\mathrm{Br}$ environment. We note that the period of the EXAFS oscillations is larger for the two oxides $\mathrm{NaBrO}_{3}$ and $\mathrm{KBrO}_{3}$ than for the bromide compounds. The differences in the $k^{2} \chi(k)$ oscillations result in distinct Fourier transforms (FT), as shown in Fig. 2c for distances up to $5 \AA$. It should be noted that the spectra are uncorrected for the phase shift of the photoelectron wave. The peaks at $\sim 1.30,2.18,2.33,2.42$ and $2.7 \AA$ correspond to the distances of the first coordination shell of Br by $\mathrm{O}, \mathrm{Fe}, \mathrm{Na}, \mathrm{Ca}$ and $\mathrm{K}$ atoms respectively, as explained hereafter. The position of each peak in the FT is phase-shifted to lower $\mathrm{r}$ by approximately $0.5 \AA$ with respect to the actual average bond distance that corresponds to each peak. Theoretical backscattering amplitude and phase shift functions for $\mathrm{Br}-\mathrm{O}, \mathrm{Br}-\mathrm{alkali}(\mathrm{Na}$ and/or $\mathrm{K}), \mathrm{Br}-\mathrm{Fe}$, and $\mathrm{Br}-\mathrm{Ca}$ were calculated using the crystallographic structures of $\mathrm{NaBrO}_{3}$ (Abrahams and Bernstein, 1977; Templeton and Templeton, 1985), $\mathrm{KBrO}_{3}$ (Templeton and Templeton, 1985; Szafranski and Ståhl, 1994), KBr (Meisalo and Inkinen, 1963; Szafranski and Ståhl, 1994), $\mathrm{NaBr}$ (Rao and Sanyal, 1990), FeBr 2 (Wilkinson et al., 1959, Haberecht et al., 2001) and $\mathrm{CaBr}_{2}$ (Brackett et al., 1963; Kennedy and Howard, 2004). The fitting routine was tested on the crystalline standards and the structural parameters derived from the 
EXAFS analysis (Table 2) were found to be consistent with the relevant EXAFS literature $\left(\mathrm{NaBrO}_{3}\right.$ : Feiters, 2004; $\mathrm{KBrO}_{3}$ : Templeton and Templeton, 1985; $\mathrm{NaBr}$ and $\mathrm{KBr}$ : Lagarde et al., 1976; Freund et al., 1991; KBr: Di Cicco et al., 1996). The EXAFS fitting models successfully identify the main contributions of $\mathrm{O}, \mathrm{Na}, \mathrm{K}, \mathrm{Fe}$ and $\mathrm{Ca}$ in the first coordination shell around the $\mathrm{Br}$ atom for the reference compounds of interest. The coordination numbers, average distance to $\mathrm{Br}$, DebyeWaller factor $\sigma^{2}$, energy shift $\Delta E_{0}$, amplitude reduction factor $S_{0}{ }^{2}$ and R-factor determined for the reference compounds are presented in Table 2 and compare favourably with previous XRD structure refinements and XAS data. The analyses for these standards provided the atom pair correlations (or paths) for the atom clusters $\mathrm{Br}-\mathrm{O}, \mathrm{Br}-\mathrm{Na}, \mathrm{Br}-\mathrm{K}, \mathrm{Br}-\mathrm{Fe}$ and $\mathrm{Br}-\mathrm{Ca}$ which were used in the fitting routines for the high-pressure glasses and melts. The amplitude reduction factor, $S_{0}{ }^{2}$, was fitted for all crystalline references (Table 2$)$ and set to the value obtained for $\mathrm{NaBrO}_{3}(0.82 \pm$ 0.04) for the analysis of the silicate glasses and high-pressure silicate melts.

\subsection{High-pressure glasses and melts}

The normalised Br K-edge XANES spectra of the parent glass, the in situ melts (M) at 2.1, 3.4 and 7.6 $\mathrm{GPa}$ and the corresponding glasses quenched from high pressure (Q) are shown in Fig. 3a. Unfortunately it was not possible to record a spectrum on the glass quenched from 7.6 GPa as the cell blew out just before quenching. All the spectra exhibit a constant absorption edge at $E_{0}=13478$ $\pm 0.5 \mathrm{eV}$ with a relatively broad white line with a maximum at $13482 \pm 1.5 \mathrm{eV}$. The XANES spectrum of the parent glass is similar to those previously published for alkali bromide aqueous solutions (Evans et al., 2009, Ferlat et al., 2001, Louvel, 2011). Changes in the shape of the XANES spectra are observed between the parent glass, the melts and the glasses quenched from high pressure, which suggests substantial differences in the local structure of $\mathrm{Br}$ at different $P-T$ conditions. In general, the white line intensity increases with pressure. For example, the white line intensity increases from 1.32 for the parent glass to 1.51 for the quenched $3.4 \mathrm{GPa}$ glass, and from 
1.18 for the $2.1 \mathrm{GPa}$ melt to 1.31 for the $7.6 \mathrm{GPa}$ melt. In contrast, temperature has the opposite effect as a result of the larger disorder around $\mathrm{Br}$ at high temperature.

The EXAFS oscillations for the glasses and melts are relatively weak and complex (Fig. 3b). The damping of the EXAFS amplitude at high temperature probably arises from the structural disorder induced by the high temperature conditions. Due to the small amplitudes of these oscillations, the $k^{2} \chi(k)$ have significant noise levels, especially for some of the high-pressure melts. As for the XANES spectra, the $k^{2} \chi(k)$ EXAFS data vary between the parent glass, the in situ melts and the glasses quenched from high pressure. The EXAFS oscillations of the in situ melts and of the glasses quenched from high pressure appear to be composed of at least two sinusoidal signals with one having a phase shift twice as large as the other one. This is not completely reproduced in the EXAFS oscillations for the parent glass. These differences indicate that several pair correlations contribute to the EXAFS spectra of the glasses and melts, resulting in the distinct Fourier transforms which are shown uncorrected for the phase shift of the electron wave in Fig. 3c. The Fourier transforms all exhibit the same features except for the parent glass. For the glasses quenched from high pressure and the melts, two main peaks are discernable at $\sim 1.20 \AA$ and $\sim 2.70 \AA$ with a shoulder at $\sim 3.80 \AA$. The first peak at $1.20 \AA$ approximately corresponds to the $\mathrm{Br}-\mathrm{O}$ position determined for the oxide standards, while the second peak corresponds to the $\mathrm{Br}$-alkali ( $\mathrm{Na}$ or $\mathrm{K}$ ) position determined for the reference compounds. As the literature on X-ray absorption of $\mathrm{Br}$ bearing compounds is relatively scarce, the aforementioned EXAFS results on crystalline references were used to model the local structure around $\mathrm{Br}$ in the glasses and the melts. The theoretical $\mathrm{Br}-\mathrm{O}$ backscattering amplitude, phase shift function and amplitude reduction factor calculated for the crystallographic structure of $\mathrm{NaBrO}_{3}$ (Abrahams and Bernstein, 1977; Templeton and Templeton, 1985, Feiters, 2004) were preferentially used to model the first peak in the Fourier transform of the EXAFS spectra for the glasses quenched from high pressure and the melts due to the similarities in the EXAFS signal and because a better fit was obtained. We then fitted the first Br-O contribution 
and the Br-alkali peak successively, using the theoretical $\mathrm{Br}-\mathrm{Na}$ and $\mathrm{Br}-\mathrm{K}$ backscattering amplitudes, phase shift functions and amplitude reduction factors calculated for the crystallographic structure of $\mathrm{NaBr}$ (Rao and Sanyal, 1990) and $\mathrm{KBr}$ (Meisalo and Inkinen, 1963; Szafranski and Ståhl, 1994). The best results were obtained with the Br-Na contribution from the $\mathrm{NaBr}$ structure. We therefore suggest that $\mathrm{Br}$ is preferentially surrounded by $\mathrm{Na}$ atoms instead of $\mathrm{K}$ atoms. We also fitted the EXAFS data with the theoretical $\mathrm{Br}-\mathrm{O}$ and $\mathrm{Br}-\mathrm{Na}$ backscattering amplitudes, phase shift functions and amplitude reduction factors calculated for the crystallographic structure of $\mathrm{NaBrO}_{3}$ (Abrahams and Bernstein, 1977; Templeton and Templeton, 1985, Feiters, 2004) and obtained similar results. The EXAFS data along with the final fits are plotted in Fig. 3b\&c. The results of the EXAFS analysis, including the fitting parameters, are reported in Table 3.

The EXAFS parameters derived for the melts show that the first coordination sphere of $\mathrm{Br}$ is composed of oxygen atoms with a coordination number of $\sim 2$. The $\mathrm{Br}-\mathrm{O}$ distance increases from 1.67 to $1.91 \AA$ with the increase in pressure, as shown by the shift in distance of the corresponding peak (Fig. 3c). The second coordination sphere is composed of an increasing number of $\mathrm{Na}$ atoms (from 5.8 to 6.6 ) situated at an increasing $\mathrm{Br}-\mathrm{Na}$ distance of 3.49 to $3.72 \AA$ with increasing pressure, which is also shown by the shift in distance of the corresponding peak (Fig. 3c). The EXAFS parameters derived for the glasses quenched from high pressure show that the Br local environment of the glasses is not directly comparable to the melts. The two contributions $\mathrm{Br}-\mathrm{O}$ and $\mathrm{Br}-\mathrm{Na}$ have a lower coordination number and a slightly shorter distance from the central $\mathrm{Br}$ atom (Fig. 5a\&b). For the glass quenched from $2.1 \mathrm{GPa}$, the presence of a peak at $1.5 \AA$ in the Fourier transform of the EXAFS oscillations clearly indicates the presence of a $\mathrm{Br}-\mathrm{O}$ contribution but since it is relatively weak it was impossible to obtain a reasonable fit. The EXAFS results were therefore only modelled with a Na contribution, giving a slightly greater coordination and bond distance for the $\mathrm{Na}$ shell around $\mathrm{Br}$ than if the $\mathrm{Br}-\mathrm{O}$ contribution could have been included. 
Because our EXAFS model does not reproduce the shoulder peak observed at $3.8 \AA$, we tested the possible presence of $\mathrm{Ca}, \mathrm{Si}$ and $\mathrm{Br}$ atoms in the local environment of $\mathrm{Br}$ using $\mathrm{Br}-\mathrm{Ca}$ correlations from the reference compounds, $\mathrm{Br}-\mathrm{Si}$ correlations and $\mathrm{Br}-\mathrm{Br}$ correlations respectively. However, these fitting models either did not give a reasonable fit to the experimental data or the fit quality was even worse. We cannot therefore attribute any of the above correlations to the peak that increases with pressure at $3.8 \AA$ in the Fourier transform of the EXAFS data. The presence of Si in the immediate environment of $\mathrm{Br}$ is unlikely according to MAS-NMR and XAFS studies on analog high pressure Cl-bearing (alumino)silicate glasses (Evans et al. 2008; McKeown et al., 2011; Sandland et al., 2004; Stebbins and $\mathrm{Du}, 2002$ ) that indicate that $\mathrm{Cl}$ is mainly coordinated to the network-modifying cations (e.g., alkali and alkaline-earth). In addition, Dalou \& Mysen (Dalou \& Mysen, 2015) explained in a recent study that there is no interaction between $\mathrm{Si}^{4+}$ and $\mathrm{Cl}^{-}$in hydrous aluminosilicate glasses quenched from 1.5 GPa. Even if we cannot undoubtedly rule out the presence of minor amounts of $\mathrm{Br}$ bonded to network cations $\left(\mathrm{Si}^{4+}\right.$ and $\left.\mathrm{Al}^{3+}\right)$, our structural model, represented in Figure 4, shows that $\mathrm{Br}$ in silicate melts at high pressure is surrounded by an average of $6 \mathrm{Na}$ cations at an average $\mathrm{Br}-\mathrm{Na}$ distance of $3.61 \AA$ in a structure similar to crystalline $\mathrm{NaBr}[$ or $(\mathrm{Na}, \mathrm{K}) \mathrm{Br}]$. Similar structures have been suggested for $\mathrm{Cl}$ in Ca-bearing silicate melts by Evans et al. (2008) where $\mathrm{Ca}-\mathrm{Cl}$ species could be found in a salt-like atomic arrangement and ionic bonding. Two oxygens form the closest coordination shell around $\mathrm{Br}$ ions. They originate either from a water molecule, an $-\mathrm{OH}$ molecule or from the tetrahedral silicate network at an average $\mathrm{Br}$ O distance of $1.80 \AA$. The large errors on the coordination numbers are associated with the high Rfactor, which characterizes the quality of the fit, and may result from the in situ conditions, particularly the disorder induced by the high temperature.

An alternative fitting strategy was applied to the parent glass at ambient pressure because the above fitting procedure did not give a reasonable fit to the experimental data. The EXAFS Fourier transform shows two resolved peaks at $\sim 0.90 \AA$ and $\sim 2.60 \AA$ with a shoulder at $1.75 \AA$. Following 
Louvel (2011), the fitting model combined the structure of a hydration shell $\left[\mathrm{Br}\left(\mathrm{H}_{2} \mathrm{O}\right) \mathrm{n}\right]$ and the structure from crystalline $\mathrm{NaBr}$, with the $\mathrm{Na}-\mathrm{Br}$ distance determined from the reference analyses. The hydration shell was modelled by considering that $\mathrm{Br}$ is coordinated by 6 water molecules $\left[\mathrm{Br}\left(\mathrm{H}_{2} \mathrm{O}\right)_{6}\right]^{-}$with a mean Br-O distance of $3.40 \AA$ (Ferlat et al., 2001; D'Angelo et al., 2010). The EXAFS spectrum of the parent glass at ambient pressure is accurately modelled with a first hydration shell with $3.5 \pm 0.7$ water molecules $\left(\mathrm{N}_{\mathrm{Br}-\mathrm{O}(--\mathrm{H})}\right)$ at a mean $\mathrm{Br}-\mathrm{O}$ (oxygen of solvating $\mathrm{H}_{2} \mathrm{O}$ molecules) distance of $3.36 \pm 0.09 \AA$ (Table 3) and a Br-Na shell with a coordination of $2.5 \pm 1$ and a mean $\mathrm{Br}-\mathrm{Na}$ distance of $2.91 \pm 0.37 \AA$. We attempted to apply this fitting procedure to the spectra of the other glasses and melts but were unable to obtain a reasonable fit to the experimental data. This suggests that the direct environment of $\mathrm{Br}$ in the parent glass is hydrous.

\section{Discussion}

\subsection{Bromine speciation at depth}

Our EXAFS results shed light on the bromine speciation and its local environment in silicic melts at pressures of up to 7.6 GPa. Figures $5 \mathrm{a}$ and $\mathrm{b}$ respectively show the $\mathrm{Br}$ coordination number by $\mathrm{O}$ and $\mathrm{Na}$ atoms and their corresponding $\mathrm{Br}-\mathrm{O}$ and $\mathrm{Br}-\mathrm{Na}$ distances as a function of pressure. The present results confirm the transition in $\mathrm{Br}$ speciation from a $\mathrm{Br}\left[\mathrm{Na}_{\mathrm{x}}\left(\mathrm{H}_{2} \mathrm{O}\right)_{\mathrm{y}}\right]$ complex at low pressure (parent glass) to an alkali structure at around $2 \mathrm{GPa}$ as evidenced by Louvel (2011) and shown schematically in Figure 4. Br association with $\mathrm{Na}$ and by extension $\mathrm{Cl}-\mathrm{Na}$ association, are consistent with the enhanced solubility of halogens in silicate melts with an increase in the concentration of modifier cations (Webster and de Vivo, 2002, Bureau et Métrich, 2003). In addition, $\mathrm{Br}$ is gradually surrounded by an increasing number of $\mathrm{Na}$ atoms at higher pressures (Fig. 5). In the melts and their quenched products, the Na coordination indeed increases from 5.8 to 6.6 with Br-Na relative distances increasing from 3.49 to $3.72 \AA$. A similar increase in coordination has 
been reported for the oxygen coordination of major elements ( $\mathrm{Si}, \mathrm{Al}, \mathrm{Fe}$ ) in glasses (Meade et al., 1992; Poe et al., 1992) and was later confirmed in silicate melts (Sanloup et al., 2013a, 2013b). We report here a similar behaviour for a minor and volatile element.

At present, it is difficult to determine precisely the origin of the $\sim 1.80 \AA$ oxygen contribution. It may originate either from a water molecule, an $-\mathrm{OH}$ group or an oxygen from the silicate melt network as seen for $\mathrm{Cl}$ in Cl-bearing borosilicate glasses (McKeown et al., 2011). Although the small increase with pressure in the white line intensity of the melts spectra could be consistent with a change of $\mathrm{Br}$ environment from bromide to bromate, there is no other evidence for such a dramatic change with pressure. A more likely explanation is that it is due to an increase in the local order around $\mathrm{Br}$ with pressure. For example, there is no change in the oxidation state of $\mathrm{Br}$ as the position of the edge of the EXAFS spectra, $E_{0}$, remains at $13478 \pm 0.5 \mathrm{eV}$ for all the glasses and melts. The $\mathrm{Br}$ formal charge therefore remains the same and cannot be used to decipher the bonding origin of the oxygen contribution. The presence of a $\mathrm{H}_{2} \mathrm{O}$ "hydration shell" around $\mathrm{Br}$ in the melt at high pressure appears plausible as the melts contain about 4 wt $\%$ dissolved $\mathrm{H}_{2} \mathrm{O}$. However, this hypothesis is not supported by results from NMR studies on hydrous Cl-bearing (alumino)silicate glasses quenched from 0.8 GPa (Sandland et al., 2004) which show no evidence for the replacement of $\mathrm{Na}^{+}$by $\mathrm{H}_{2} \mathrm{O}$ (or $\mathrm{OH}$ groups) in the neighbouring shell around the halide ions in glasses containing up to $5.5 \mathrm{wt} \% \mathrm{H}_{2} \mathrm{O}$. The presence of the oxygen atom from a water or $-\mathrm{OH}$ molecule at such a short distance from $\mathrm{Br}$ could also be due to the proximity of a water molecule linked to the alkali "salt-like" structure of $\mathrm{Br}$ atoms in the melt. Indeed, ${ }^{29} \mathrm{Si},{ }^{27} \mathrm{Al}$ and ${ }^{23} \mathrm{Na} \mathrm{NMR}$ studies of hydrous aluminosilicate glasses indicate that the hydration sites in the structure are preferentially located around alkali ions (Kohn, 2000; Schmidt et al., 2001). The fact that the oxygen coordination remains constant and equal to 2 within uncertainties while the $\mathrm{Br}-\mathrm{O}$ distance increases from 1.67 to $1.81 \AA$ could be another indication that this oxygen contribution arises from the proximity of a 
water molecule linked to one of the alkali ions of the salt-like structure with the greater $\mathrm{Br}-\mathrm{O}$ distance observed with pressure being due to the increasing distance of the $\mathrm{Br}-\mathrm{Na}$ bonds.

Finally, the quantitative EXAFS results presented here suggest that there is a slight structural difference between the melts and their glasses quenched from high pressure. The results reveal a slightly larger coordination of $\mathrm{Br}$ by $\mathrm{Na}$ and $\mathrm{O}$ atoms and slightly longer bond distances for the in situ melts than for the glasses quenched from high pressure, notably for the $3.4 \mathrm{GPa}$ run. The greater distances observed for the melts are most likely due to thermal disorder and the thermal expansion of the bond distances (Mysen and Richet, 2005). However, we note that the overall alkali "salt-like" structure of $\mathrm{Br}$ in the melts and in their quenched product remains comparable.

\subsection{Geological implications}

In a recent state-of-the-art study on the role of halogen elements in igneous processes, Pyle and Mather (2009) clearly pointed out the lack of knowledge of the heavy halogens Br and I, compared to $\mathrm{Cl}$ or even $\mathrm{F}$. Br has a low abundance in Earth's volcanic and mantle rocks (Newsom, 1995), from $\mathrm{ppb}$ to $\mathrm{ppm}$ in order of magnitude- These low abundances partly explain why it has been poorly studied and why much remains to be learned about it. Our results on the speciation of $\mathrm{Br}$ in high-pressure melts emphasize the influence of pressure on the speciation of $\mathrm{Br}$ in geologically relevant silicate melts. The changes observed in $\mathrm{Br}$ speciation with pressure and the observed $\mathrm{Br}-\mathrm{Na}$ complexation in melts are consistent with the available experimental data for $\mathrm{Br}$ partitioning between fluids and melts and with the enhanced solubility of halogens in silicate melts with increasing concentration of network modifying cations (Bureau et Métrich, 2003). Indeed, Br solubility has been shown to be very high in hydrous alkali silicic melts (thousands of ppm to wt.\% depending on the bulk composition), which is similar to $\mathrm{Cl}$ solubility in hydrous silicic melts (Bureau and Metrich, 2003). In addition, Br (halogens) complexation with alkalis may be an efficient mechanism for the transport and recycling of halogens, although "diluted" fluids produced 
by the dehydration of the slab may be the main carriers of halogens in subduction zones (Louvel, 2011, Bureau et al., 2010). Our results suggest that if part of the halogen elements are retained in the slab after the first dehydration steps liberating aqueous fluids, they could later be partially removed by hydrous melts produced at greater depths or by complex fluids with a high fraction of dissolved silicates (Hermann et al., 2006; Kessel et al., 2005; Manning, 2004), contributing to recycling an important fraction of halogens in subduction zones. Although the silicic melt investigated is different from the magma produced by mantle melting upon fluid release, as we had to investigate a composition with a great Br solubility to record good EXAFS spectra, we suggest that the incorporation of $\mathrm{Br}$ in the structure of silicate melts at high pressure should favour their transport from the slab to the mantle wedge and most likely to the volcanic arc. Halogens in the volcanic arc are strongly involved in mantle fertilization processes (John et al., 2011) and may play a critical role in volcanic degassing by influencing the properties of the magmas (e.g. viscosity, phase relations, diffusion) (Aiuppa et al., 2009). Indeed, natural volcanic products related to subduction zone volcanism are enriched in halogen elements (Roggensack et al., 1997; Wallace, 2005; Straub and Layne, 2003, Kent et al., 2002) and it has recently been confirmed that subduction zones may be a major source of halogen elements in the Earth's mantle (Kendrick et al., 2014).

The presence of $\mathrm{Br}$ in the melt structure at high pressure and the increasing number of $\mathrm{Na}$ atoms in its local environment with increasing pressure show that $\mathrm{Br}$ has the potential to be stored deeper in Earth's mantle than previously supposed. This could explain the traces of Br detected in inclusions trapped in ultra deep eclogitic diamonds (Johnson et al., 2000; Burgess et al., 2002). Finally, the differences observed between the parent glass quenched under low pressure $(0.2 \mathrm{GPa})$ and the melts or glasses quenched from high-pressure implies that glasses quenched from ambient pressure may not be good candidates to represent the local environment of volatile elements in silicate melts at high pressure. It also confirms the high values of $\mathrm{Br}$ partitioning between fluid and glass obtained by Bureau et al. (2010) that showed that almost all of the Br contained in the melt was exsolved into 
the aqueous fluid during the experimental quench at low pressures $(<1.7 \mathrm{GPa})$. Such results could indicate that the shallow repartitioning of the halogens, during the Hadean when the Earth was a magma ocean, was determined by water degassing. Indeed, if we assume that the halogen cycle is linked to the Earth's water cycle, halogen elements may have been efficiently degassed during the early stages of an oxidized magma ocean.

\section{Conclusion}

Our results show that $\mathrm{Br}$ anions form $\mathrm{NaBr}$ complexes in the hydrous melts under pressure. $\mathrm{BrOH}$ complexes are also probably formed but further investigation is needed to elucidate the origin of the $\mathrm{Br}-\mathrm{O}$ contribution present in our work. The increase with pressure of the mean coordination of $\mathrm{Na}$ ions around $\mathrm{Br}$, a minor and volatile element, is similar to that observed for the oxygen coordination of major elements. In addition, our results confirm that $\mathrm{Br}$ can be more concentrated in the hydrous silicate melt or supercritical melt as compared to aqueous fluid when pressure (i.e. depth) increases (Bureau et al., 2010) and support the idea of a deep recycling of $\mathrm{Br}$, at least at depths of $>150 \mathrm{~km}$ in the upper mantle, i.e. deeper than the location of arc magma genesis where the presence of $\mathrm{Br}$ has been found in saline inclusions in natural diamonds from the upper mantle (Johnson et al., 2000). Furthermore, the results suggest that $\mathrm{Br}$, and by extension $\mathrm{Cl}$ and $\mathrm{I}$, are efficiently degassed with water during eruption and that $\mathrm{Br}$ may also have been efficiently degassed with water during the early stages of an oxidized magma ocean.

\section{Acknowledgments}

The EXAFS experiments were conducted at ESRF (proposals HC776 and HD563). We thank C. Martel for supplying the parent glass, R. Champalier and G. Prouteau for glass synthesis, C. 
Hayward for his help with electron microprobe analyses, J.W.E. Drewitt and O. Mathon for their help with the EXAFS experiments, M. Roberge, C. Raepsaet and the LEEL staff who helped us during PIXE sessions, J.W.E. Drewitt and J. Hudspeth for proofreading this manuscript. Constructive reviews from an anonymous reviewer and the AE improved the manuscript. The SEM facility of IMPMC is supported by Region Ile de France Grant SESAME 2006 NOI-07-593/R, INSU-CNRS, UPMC and ANR grant ANR-07-BLAN- 0124-01. This work was supported by the European Research Council under the European Community's Seventh Framework Programme (FP7/20072013 Grant Agreement No. 259649 to C.S.). 


\section{References}

Abrahams, S.C., Bernstein, J.L., 1977. Remeasurement of optically active $\mathrm{NaClO}_{3}$ and $\mathrm{NaBrO}_{3}$. Acta Crystallographica Section B: Structural Crystallography and Crystal Chemistry 33, 3601-3604.

Aiuppa, A., Baker, D.R., Webster, J.D., 2009. Halogens in volcanic systems. Chemical Geology 263, 1-18. doi:10.1016/j.chemgeo.2008.10.005

Alletti, M., Baker, D.R., Freda, C., 2007. Halogen diffusion in a basaltic melt. Geochimica et Cosmochimica Acta 71, 3570-3580.

Baasner, A., Schmidt, B., Webb, S., 2013. Compositional dependence of the rheology of halogen (F, Cl) bearing aluminosilicate melts. Chemical Geology 346, 172-183.

Baker, D.R., Balcone-Boissard, H., 2009. Halogen diffusion in magmatic systems: Our current state of knowledge. Chemical Geology 263, 82-88.

Brackett, E.B., Brackett, T.E., Sass, R.L., 1963. The crystal structure of calcium bromide. Journal of Inorganic and Nuclear Chemistry 25, 1295-1296.

Bureau, H., Foy, E., Raepsaet, C., Somogyi, A., Munsch, P., Simon, G., Kubsky, S., 2010. Bromine cycle in subduction zones through in situ Br monitoring in diamond anvil cells. Geochimica et Cosmochimica Acta 74, 3839-3850.

Bureau, H., Keppler, H., Metrich, N., 2000. Volcanic degassing of bromine and iodine: experimental Fluid/melt partitioning data and applications to stratospheric chemistry. Earth and Planetary Science Letters 183, 51-60.

Bureau, H., Métrich, N., 2003. An experimental study of bromine behaviour in water-saturated silicic melts. Geochimica et Cosmochimica Acta 67, 1689-1697.

Bureau, H., Raepsaet, C., Khodja, H., Carraro, A., Aubaud, C., 2009. Determination of hydrogen content in geological samples using elastic recoil detection analysis (ERDA). Geochimica et Cosmochimica Acta 73, 3311-3322.

Burgess, R., Layzelle, E., Turner, G., Harris, J.W., 2002. Constraints on the age and halogen composition of mantle fluids in Siberian coated diamonds. Earth and Planetary Science Letters 197, 193-203.

Chevychelov, V.Y., Bocharnikov, R.E., Holtz, F., 2008. Experimental study of chlorine and fluorine partitioning between fluid and subalkaline basaltic melt. Doklady Earth Sciences 422, 1089-1092.

Dalou, C., Mysen, B.O., 2015. The effect of $\mathrm{H}_{2} \mathrm{O}$ on $\mathrm{F}$ and $\mathrm{Cl}$ solubility and solution mechanisms of in aluminosilicate melts at high pressure and high temperature. American Mineralogist 100, 633-643.

D’Angelo, P., Migliorati, V., Guidoni, L., 2010. Hydration Properties of the Bromide Aqua Ion: the Interplay of First Principle and Classical Molecular Dynamics, and X-ray Absorption Spectroscopy. Inorganic Chemistry 49, 4224-4231.

Di Cicco, A., Rosolen, M.J., Marassi, R., Tossici, R., Filipponi, A., Rybicki, J., 1996. Short-range order in solid and liquid KBr probed by EXAFS. Journal of Physics: Condensed Matter 8, 10779.

Edmonds, M., Gerlach, T.M., Herd, R.A., 2009. Halogen degassing during ascent and eruption of water-poor basaltic magma. Chemical Geology 263, 122-130.

Evans, K., Gordon, R., Mavrogenes, J., Tailby, N., 2009. The effect of CO2 on the speciation of RbBr in solution at temperatures to $579^{\circ} \mathrm{C}$ and pressures to $0.26 \mathrm{GPa}$. Geochimica et Cosmochimica Acta 73, 2631-2644.

Evans, K.A., Mavrogenes, J.A., O’Neill, H.S., Keller, N.S., Jang, L.-Y., 2008. A preliminary investigation of chlorine XANES in silicate glasses. Geochemistry, Geophysics, Geosystems 9, 10, 1-15.

Feiters, M.C., Kupper, F.C., Meyer-Klaucke, W., 2004. X-ray absorption spectroscopic studies on model compounds for biological iodine and bromine. Journal of synchrotron radiation 12, 85-93.

Ferlat, G., San Miguel, A., Jal, J., Soetens, J., Bopp, P., Daniel, I., Guillot, S., Hazemann, J., Argoud, R., 2001. Hydration of the bromine ion in a supercritical 1:1 aqueous electrolyte. Physical Review B 63. 
Filipponi, A., Borowski, M., Bowron, D.T., Ansell, S., Di Cicco, A., De Panfilis, S., Itiè, J.-P., 2000. An experimental station for advanced research on condensed matter under extreme conditions at the European Synchrotron Radiation Facility - BM29 beamline. Review of Scientific Instruments 71, 2422.

Freund, J., Ingalls, R., Crozier, E.D., 1991. Extended x-ray-absorption fine-structure study of alkali-metal halides under high pressure. Physical Review B 43, 9894.

Haberecht, J., Borrmann, H., Kniep, R., 2001. Refinement of the crystal structure of iron dibromide, FeBr2. Z. Krist.New Cryst. Struct. 216, 510-510.

Hermann, J., Spandler, C., Hack, A., Korsakov, A., 2006. Aqueous fluids and hydrous melts in high-pressure and ultrahigh pressure rocks: Implications for element transfer in subduction zones. Lithos 92, 399-417.

Irifune, T, Kurio, A, Sakamoto, S., Inoue, T, Sumiya, H, 2003. Ultrahard polycrystalline diamond from graphite. Nature Communications 421, 599-600.

John, T., Scambelluri, M., Frische, M., Barnes, J.D., Bach, W., 2011. Dehydration of subducting serpentinite: Implications for halogen mobility in subduction zones and the deep halogen cycle. Earth and Planetary Science Letters $308,65-76$.

Johnson, L.H., Burgess, R., Turner, G., Milledge, H.J., Harris, J.W., 2000. Noble gas and halogen geochemistry of mantle fluids: comparison of African and Canadian diamonds. Geochimica et Cosmochimica Acta 64, 717-732.

Kendrick, M.A., Arculus, R.J., Danyushevsky, L.V., Kamenetsky, V.S., Woodhead, J.D., Honda, M., 2014. Subductionrelated halogens $(\mathrm{Cl}, \mathrm{Br}$ and $\mathrm{I})$ and $\mathrm{H} 2 \mathrm{O}$ in magmatic glasses from Southwest Pacific Backarc Basins. Earth and Planetary Science Letters 400, 165-176.

Kennedy, B., Howard, C., 2004. Synchrotron x-ray powder diffraction study of the structural phase transition in CaBr2. Physical Review B 70.

Kent, A.J., Peate, D.W., Newman, S., Stolper, E.M., Pearce, J.A., 2002. Chlorine in submarine glasses from the Lau Basin: seawater contamination and constraints on the composition of slab-derived fluids. Earth and Planetary Science Letters 202, 361-377.

Kessel, R., Schmidt, M.W., Ulmer, P., Pettke, T., 2005. Trace element signature of subduction-zone fluids, melts and supercritical liquids at 120-180 km depth. Nature 437, 724-727.

Khodja, H., Berthoumieux, E., Daudin, L., Gallien, J.-P., 2001. The Pierre Süe Laboratory nuclear microprobe as a multi-disciplinary analysis tool. Nuclear Instruments and Methods in Physics Research Section B: Beam Interactions with Materials and Atoms 181, 83-86.

Kohn, S., Dupree, R., Mortuza, M., 1992. The interaction between water and aluminosilicate magmas. Chemical Geology 96, 399-409.

Lagarde, P., 1976. Experimental and theoretical studies of extended x-ray absorption fine structure in bromine salts ( $\mathrm{NaBr}$ and $\mathrm{KBr}$ ). Physical Review B 14, 741.

Losq, C., Neuville, D., Moretti, R., Roux, J., 2012. Determination of water content in silicate glasses using Raman spectrometry: implications for the study of explosive volcanism. American Mineralogist 97, 779-790.

Louvel, M., 2011. Trace elements in subduction zone fluids. Diss., Eidgenössische Technische Hochschule ETH Zürich, Nr. 20082, 2011.

Louvel, M., Sanchez-Valle, C., Malfait, W., Testemale, D., Hazemann, J., 2013. Zr complexation in high pressure fluids and silicate melts and implications for the mobilization of HFSE in subduction zones. Geochimica et Cosmochimica Acta 104, 281-299.

Manning, C., 2004. The chemistry of subduction-zone fluids. Earth and Planetary Science Letters 223, 1-16.

Martel, C., Pichavant, M., Bourdier, J.-L., Traineau, H., Holtz, F., Scaillet, B., 1998. Magma Storage conditions and control of eruptions regime in silicic volcanoes: experimental evidence from Mt. Pelée. Earth and Planetary Science Letters 156, 89-99. 
Mayanovic, R.A., Yan, H., Anderson, A.J., Solferino, G., 2013. Investigation of the structural environment of Ta in a silicate glass and water system under high P-T conditions. Journal of Non-Crystalline Solids 368, 71-78.

McKeown, D.A., Gan, H., Pegg, I.L., Stolte, W.C., Demchenko, I.N., 2011. X-ray absorption studies of chlorine valence and local environments in borosilicate waste glasses. Journal of Nuclear Materials 408, 236-245.

Meade, C., Hemley, R.J., Mao, H.K., 1992. High-pressure X-ray diffraction of SiO 2 glass. Physical review letters 69 , 1387.

Meisalo, V., Inkinen, O., 1967. An X-ray diffraction analysis of potassium bromide. Acta Crystallographica 22, $58-65$.

Mysen B.O. et Richet P., 2005 Silicate glasses and melts : Properties and structure. Elsevier, Amsterdam.

Newsom H. E. (1995) Composition of the solar system, planets meteorites and major terrestrial reservoirs. In Global Earth Physics (ed. T. J. Ahrens). American Geophysical Union, Washington, DC, pp. 159-189.

Newville, M., 2001. EXAFS analysis using FEFF and FEFFIT. Journal of Synchrotron Radiation 8.

Pokrovski, G., Roux, J., Ferlat, G., Jonchiere, R., Seitsonen, A., Vuilleumier, R., Hazemann, J., 2013. Silver in geological fluids from in situ X-ray absorption spectroscopy and first-principles molecular dynamics. Geochimica et Cosmochimica Acta 106, 501-523.

Poe, B., McMillan, P., Austen Angell, C., Sato, R.K., 1992. Al and Si coordination in SiO2-A1203glasses and liquids: A study by NMR and IR spectroscopy and MD simulations. Chemical Geology 96, 333-349.

Pyle, D.M., Mather, T.A., 2009. Halogens in igneous processes and their fluxes to the atmosphere and oceans from volcanic activity: A review. Chemical Geology 263, 110-121.

Rao, B.S., Sanyal, S.P., 1990. Structural and elastic properties of sodium halides at high pressure. Physical Review B 42,1810 .

Ravel, B., Newville, M., 2005. ATHENA, ARTEMIS, HEPHAESTUS: data analysis for X-ray absorption spectroscopy using IFEFFIT. Journal of Synchrotron Radiation 12, 537-541.

Roggensack K., Hervig R. L., McKnight S. B., Williams S. N., 1997. Explosive basaltic volcanism from Cero Negro volcano: influence of volatiles on eruptive style. Science 277, 1639-1642.

Sandland, T.O., Du, L.-S., Stebbins, J.F., Webster, J.D., 2004. Structure of Cl-containing silicate and aluminosilicate glasses: A 35Cl MAS-NMR study. Geochimica et Cosmochimica Acta 68, 5059-5069.

Sanloup, C., Drewitt, J.W.E., Konôpková, Z., Dalladay-Simpson, P., Morton, D.M., Rai, N., van Westrenen, W., Morgenroth, W., 2013. Structural change in molten basalt at deep mantle conditions. Nature 503, 104-107.

Sanloup, C., Drewitt, J.W.E., Crépisson, C., Kono, Y., Park, C., McCammon, C., Hennet, L., Brassamin, S., Bytchkov, A., 2013. Structure and density of molten fayalite at high pressure. Geochimica et Cosmochimica Acta 118, 118-128.

Schmidt, B., Behrens, H., Riemer, T., Kappes, R., Dupree, R., 2001. Quantitative determination of water speciation in aluminosilicate glasses: a comparative NMR and IR spectroscopic study. Chemical Geology 174, 195-208.

Signorelli S., Carroll M., 2002. Experimental study of Cl solubility in hydrous alkaline melts: constraints on the theoretical maximum amount of $\mathrm{Cl}$ in trachytic and phonolitic melts. Contributions to Mineralogy and Petrology 143, 209-218.

Soldatov, A., Ivanchenko, T., Stekhin, I., Bianconi, A., 1993. X-ray absorption fine-structure investigation of the ionic compounds $\mathrm{NaBr}, \mathrm{KBr}$ and $\mathrm{RbCl}$ : full multiple-scattering analysis. Journal of Physics: Condensed Matter 5, 7521.

Stebbins, J.F., Du, L.-S., 2002. Chloride ion sites in silicate and aluminosilicate glasses: A preliminary study by $35 \mathrm{Cl}$ solid-state NMR 87, 359-363.

Straub, S.M., Layne, G.D., 2003. The systematics of chlorine, fluorine, and water in Izu arc front volcanic rocks: implications for volatile recycling in subduction zones. Geochimica et Cosmochimica Acta 67, 4179-4203. 
Szafranski, M., Ståhl, K., 1994. Refinements of the crystal structures and UV-absorption properties of KBrO3, RbBrO3 and CsBrO3. Zeitschrift für Kristallographie - Crystalline Materials 209, 491-494.

Templeton, D.H., Templeton, L.K., 1985. Tensor X-ray optical properties of the bromate ion. Acta Crystallographica Section A: Foundations of Crystallography 41, 133-142.

Testemale, D., Brugger, J., Liu, W., Etschmann, B., Hazemann, J.-L., 2009. In-situ X-ray absorption study of Iron(II) speciation in brines up to supercritical conditions. Chemical Geology 264, 295-310.

Van Kan Parker, M., Sanloup, C., Tronche, E., Perrillat, J., Mezouar, M., Rai, N., Van Westrenen, W., 2010. Calibration of a diamond capsule cell assembly for in situ determination of liquid properties in the Paris-Edinburgh press. High Pressure Research 30, 332-341.

Wallace, P.J., 2005. Volatiles in subduction zone magmas: concentrations and fluxes based on melt inclusion and volcanic gas data. Journal of Volcanology and Geothermal Research 140, 217-240. doi:10.1016/j.jvolgeores.2004.07.023

Wallen, S.L., Palmer, B.J., Pfund, D.M., Fulton, J.L., Newville, M., Ma, Y., Stern, E.A., 1997. Hydration of Bromide Ion in Supercritical Water: An X-ray Absorption Fine Structure and Molecular Dynamics Study. J. Phys. Chem. A 9632-9640.

Webster, J.D., 1992. Fluid-melt interactions involving Cl-rich granites: experimental study from 2 to 8 kbar. Geochimica et Cosmochimica Acta 56, 659-678.

Webster, J.D., De Vivo, B., 2002. Experimental and modeled solubilities of chlorine in aluminosilicate melts, consequences of magma evolution, and implications for exsolution of hydrous chloride melt at Mt. Somma-Vesuvius. American Mineralogist 87, 1046-1061.

Wilkinson, M.K., Cable, J.W., Wollan, E.O., Koehler, W.C., 1959. Neutron Diffraction Investigations of the Magnetic Ordering in $\mathrm{FeBr} 2, \mathrm{CoBr} 2, \mathrm{FeCl} 2$ and Cocl2. Physical Review 113, 497. 


\section{Figures}

Figure 1: a) SEM image of the glass quenched from 3.4 GPa recorded at IMPMC, CNRS, Paris showing the homogeneity of the quenched sample as well as the lack of large scale crystallization of the high-pressure recovered quenched sample. The $0.1 \times 0.5 \mathrm{~mm}^{2}$ EXAFS beam was centred in the middle of the capsule. b) Raman spectrum of the glass quenched from $3.4 \mathrm{GPa}$ plotted after baseline subtraction. The water content was determined after calculating the ratio, $\mathrm{R}_{w} / \mathrm{s}$, between the "silicate" region's area, As, and the "water" region's area, $A_{W}$, as $R_{W} / s=A_{W} / A_{s}$, then correlating it with the empirical calibration of Le Losq et al. (2010).

Figures 2: Normalized X-ray absorption spectra (a), $k^{2}$-weighted $\chi(k)$ EXAFS oscillations (b) and Fourier transforms (c) for crystalline bromine model compounds at ambient conditions. The spectra have been shifted in the vertical direction for clarity. Red dashed lines are least-square fits performed using IFEFFIT. Contributions around the $\mathrm{Br}$ atom arising from the first neighbours are labelled. Peak positions are uncorrected from backscattering phase shift (c). The corrected interatomic distances are reported in Table 2. For reason of clarity the amplitude of the $k^{2}$-weighted $\square(k)$ EXAFS oscillations and Fourier transforms of $\mathrm{NaBrO}_{3}$ and $\mathrm{KBrO}_{3}$ reference compounds have been divided by two.

Figures 3: Normalized X-ray absorption spectra (a), $k^{2}$-weighted $\chi(k)$ EXAFS oscillations (b) and Fourier transforms (c) for the starting glass at ambient pressure, the glasses quenched from high pressure $(Q)$ and the melts (M) at the pressure indicated in GPa. Red dashed lines are least-square fits performed using IFEFFIT. Peak positions are uncorrected from backscattering phase shift (c). The corrected interatomic distances are reported in Table 3.

Figure 4: Schematic representation of the Br speciation in high pressure silicate melts. The proposed model obtained from the EXAFS experiments shows a transition in $\mathrm{Br}$ speciation from a $\mathrm{Br}\left[\mathrm{Na}_{\mathrm{x}}\left(\mathrm{H}_{2} \mathrm{O}\right)_{\mathrm{y}}\right]$ complex at low pressure (parent glass) to a $\mathrm{Br}$ atom surrounded by an increasing number of $\mathrm{Na}$ ions with two oxygen atoms at $\mathrm{P} \geq 2 \mathrm{GPa}$. Colour code is the following: $\mathrm{Br}$ (large green), $\mathrm{Na}$ (large purple), $\mathrm{O}$ (light blue) and $\mathrm{H}$ (pink). The lines between the $\mathrm{Na}$ atoms are guides to the eyes.

Figure 5: Evolution of (a) bromine coordination numbers $\left(\mathrm{N}_{\mathrm{Br}-\mathrm{O} . . \mathrm{H}}, \mathrm{N}_{\mathrm{Br}-\mathrm{O}}\right.$ and $\left.\mathrm{N}_{\mathrm{Br}-\mathrm{Na}}\right)$ and (b) distances $(\mathrm{Br}$ $\mathrm{O} . . \mathrm{H}, \mathrm{Br}-\mathrm{O}$ and $\mathrm{Br}-\mathrm{Na}$ ) as a function of pressure for the melts (open symbols and dashed lines) and the glasses quenched from high pressure (plain symbols and line). 
Table 1: Chemical composition ${ }^{a}$ (wt \%) of the starting material and of the recovered glass samples

\begin{tabular}{lccc}
\hline & Parent & Quenched & Quenched \\
& Glass & Glass & Glass \\
& & $2.1 \mathrm{GPa}$ & $3.4 \mathrm{GPa}$ \\
& & & \\
\hline $\mathrm{SiO}_{2}$ & $73.27_{(70)}$ & $71.29_{(58)}$ & $71.50_{(72)}$ \\
$\mathrm{TiO}_{2}$ & $0.30_{(1)}$ & $0.29_{(7)}$ & $0.28_{(1)}$ \\
$\mathrm{Al}_{2} \mathrm{O}_{3}$ & $12.20_{(30)}$ & $11.93_{(25)}$ & $13.23_{(33)}$ \\
$\mathrm{FeO}^{\mathrm{b}}$ & $0.83_{(16)}$ & $0.04_{(12)}$ & $0.02_{(10)}$ \\
$\mathrm{MgO}$ & $0.41_{(4)}$ & $0.40_{(19)}$ & $0.41_{(5)}$ \\
$\mathrm{MnO}$ & $0.08_{(1)}$ & $0.09_{(2)}$ & $0.04_{(1)}$ \\
$\mathrm{CaO}$ & $2.29_{(14)}$ & $2.19_{(13)}$ & $2.26_{(14)}$ \\
$\mathrm{Na}_{2} \mathrm{O}$ & $4.19_{(21)}$ & $4.79_{(29)}$ & $4.85_{(23)}$ \\
$\mathrm{K}_{2} \mathrm{O}$ & $1.60_{(13)}$ & $1.62_{(18)}$ & $1.73_{(14)}$ \\
$\mathrm{P}_{2} \mathrm{O}_{5}$ & $0.01_{(1)}$ & $0.01_{(1)}$ & $0.01_{(1)}$ \\
$\mathrm{Cl}$ & $0.01_{(1)}$ & $0.01_{(2)}$ & $0.01_{(1)}$ \\
$\mathrm{Br}^{\mathrm{c} / \mathrm{d}}$ & $2.20_{(22)} / 2.28_{(13)}$ & $2.27_{(31)} / 2.21_{(15)}$ & $2.27_{(22)} / 1.97_{(12)}$ \\
$\mathrm{H}_{2} \mathrm{O}^{\mathrm{e} / \mathrm{f}}$ & $3.50_{(50)} / 3.72_{(36)}$ & $4.20_{(50)} /-$ & $3.80_{(50)} / 4.41_{(43)}$ \\
& & & \\
\hline
\end{tabular}

\footnotetext{
${ }^{a}$ Average of 10 analyses given with the standard deviation (number in brackets) in terms of the least unit cited.

${ }^{\mathrm{b}}$ Total iron reported as $\mathrm{FeO}$

${ }^{c}$ determined by PIXE analysis

${ }^{\mathrm{d}}$ determined by electron microprobe analyses

e determined by Raman spectroscopy

${ }^{\mathrm{f}}$ determined by ERDA analysis
} 
Table 2: EXAFS-derived structural parameters for the crystalline reference compounds

\begin{tabular}{|c|c|c|c|c|c|c|c|c|}
\hline & Bond type & C.N. ${ }^{a}$ & $\mathbf{d}(\AA)$ & R-factor & $\sigma^{2}\left(\AA^{-2} 10^{-3}\right)^{b}$ & $\Delta \mathbf{E}_{\mathbf{0}}(\mathbf{e V})^{\mathrm{c}}$ & $\mathbf{S}_{0}{ }^{2 \mathrm{~d}}$ & literature (see text) \\
\hline $\mathrm{CaBr}_{2}$ & $\mathrm{Br}-\mathrm{Ca}$ & $3.1 \pm 0.3$ & $2.90 \pm 0.02$ & 0.002 & $0.01 \pm 0.002$ & $4.12 \pm 0.55$ & $0.49 \pm 0.04$ & $3^{*} \mathrm{Ca}$ at $2.89 \AA$ \\
\hline $\mathrm{FeBr}_{2}$ & $\mathrm{Br}-\mathrm{Fe}$ & $2.8 \pm 0.7$ & $2.77 \pm 0.03$ & 0.007 & $0.13 \pm 0.008$ & $0.47 \pm 1.19$ & $0.92 \pm 0.03$ & $3 * \mathrm{Fe}$ at $2.63 \AA$ \\
\hline $\mathrm{NaBr}$ & $\mathrm{Br}-\mathrm{Na}$ & $6.1 \pm 0.4$ & $2.97 \pm 0.01$ & 0.007 & $0.03 \pm 0.01$ & $-1.40 \pm 0.82$ & $0.43 \pm 0.05$ & $6^{*} \mathrm{Na}$ at $2.98 \AA$ \\
\hline KBr & $\mathrm{Br}-\mathrm{K}$ & $6.3 \pm 0.6$ & $3.24 \pm 0.06$ & 0.024 & $0.01 \pm 0.002$ & $1.64 \pm 0.85$ & $0.56 \pm 0.08$ & $6^{*} \mathrm{~K}$ at $3.30 \AA$ \\
\hline $\mathrm{KBrO}_{3}$ & $\mathrm{Br}-\mathrm{O}$ & $3.0 \pm 0.3$ & $1.67 \pm 0.01$ & 0.019 & $0.01 \pm 0.001$ & $1.42 \pm 0.99$ & $0.69 \pm 0.05$ & $3 * O$ at $1.66 \AA$ \\
\hline $\mathrm{NaBrO}_{3}$ & $\mathrm{Br}-\mathrm{O}$ & $3.2 \pm 0.2$ & $1.69 \pm 0.04$ & 0.018 & $0.005 \pm 0.001$ & $1.84 \pm 0.82$ & $0.82 \pm 0.04$ & $3 * \mathrm{O}$ at $1.66 \AA$ \\
\hline
\end{tabular}

${ }^{\text {a }}$ Average coordination number

${ }^{\mathrm{b}}$ Debye-Waller factor

${ }^{c}$ Difference between the initial model nearest neighbour distance and the real distance

${ }^{\mathrm{d}}$ Amplitude reduction factor 
Table 3: EXAFS-derived structural parameters for the parent glass, the melts and the glasses quenched from high pressure

\begin{tabular}{|c|c|c|c|c|c|c|c|}
\hline & Bond type & C. $\mathbf{N}^{\mathrm{a}}$ & d $(\AA)$ & $\sigma^{2}\left(\AA^{-2} 10^{-3}\right)^{b}$ & R-factor & $\Delta \mathbf{E}_{\mathbf{0}}(\mathbf{e V})^{\mathrm{c}}$ & $\sigma^{3 d}$ \\
\hline \multirow{2}{*}{ Parent glass } & $\mathrm{Br}-\mathrm{Na}$ & $2.5 \pm 1$ & $2.91 \pm 0.37$ & \multirow{2}{*}{$0.02 \pm 0.02$} & \multirow{2}{*}{0.02} & \multirow{2}{*}{$4.39 \pm 0.61$} & \multirow{2}{*}{-} \\
\hline & $\mathrm{Br}-\mathrm{O}(--\mathrm{H})$ & $3.5 \pm 0.7$ & $3.36 \pm 0.09$ & & & & \\
\hline \multicolumn{8}{|l|}{ Glasses } \\
\hline $\mathrm{Q}-2.1 \mathrm{GPa}$ & $\mathrm{Br}-\mathrm{Na}$ & $6.5 \pm 0.4$ & $3.63 \pm 0.18$ & $0.09 \pm 0.01$ & 12 & $-4.58 \pm 0.11$ & 0.008 \\
\hline \multirow{2}{*}{$Q-3.4$ GPa } & $\mathrm{Br}-\mathrm{O}$ & $1.5 \pm 0.6$ & $1.68 \pm 0.33$ & $0.03 \pm 0.02$ & \multirow{2}{*}{0.04} & \multirow{2}{*}{$3.25 \pm 1.02$} & \multirow{2}{*}{0.024} \\
\hline & $\mathrm{Br}-\mathrm{Na}$ & $5.3 \pm 0.3$ & $3.54 \pm 0.87$ & $0.01 \pm 0.07$ & & & \\
\hline Melts & & & & 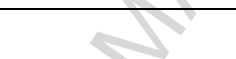 & & & \\
\hline \multirow{2}{*}{$\mathrm{M}-2.1 \mathrm{GPa}$} & $\mathrm{Br}-\mathrm{O}$ & $2.0 \pm 0.2$ & $1.67 \pm 0.02$ & $0.07 \pm 0.03$ & \multirow{2}{*}{0.02} & \multirow{2}{*}{$3.79 \pm 1.19$} & \multirow{2}{*}{0.005} \\
\hline & $\mathrm{Br}-\mathrm{Na}$ & $5.8 \pm 0.2$ & $3.49 \pm 0.05$ & $0.05 \pm 0.01$ & & & \\
\hline \multirow{2}{*}{ M - 3.4 GPa } & $\mathrm{Br}-\mathrm{O}$ & $2.2 \pm 0.3$ & $1.83 \pm 0.18$ & $0.19 \pm 0.02$ & \multirow{2}{*}{0.03} & \multirow{2}{*}{$5.95 \pm 2.42$} & \multirow{2}{*}{0.012} \\
\hline & $\mathrm{Br}-\mathrm{Na}$ & $6.1 \pm 0.4$ & $3.63 \pm 0.3$ & $0.06 \pm 0.03$ & & & \\
\hline \multirow{2}{*}{$\mathrm{M}$ - 7.6 GPa } & $\mathrm{Br}-\mathrm{O}$ & $2.1 \pm 0.6$ & $1.91 \pm 0.23$ & $0.05 \pm 0.03$ & \multirow{2}{*}{0.19} & \multirow{2}{*}{$1.90 \pm 0.92$} & \multirow{2}{*}{0.001} \\
\hline & $\mathrm{Br}-\mathrm{Na}$ & $6.6 \pm 0.7$ & $3.72 \pm 0.57$ & $0.03 \pm 0.01$ & & & \\
\hline
\end{tabular}

\footnotetext{
${ }^{a}$ Average coordination number

${ }^{\mathrm{b}}$ Debye-Waller factor

${ }^{c}$ Difference between the initial model nearest neighbour distance and the real distance

${ }^{\mathrm{d}}$ Third order anharmonic cumulant-expansion fitting parameter
} 


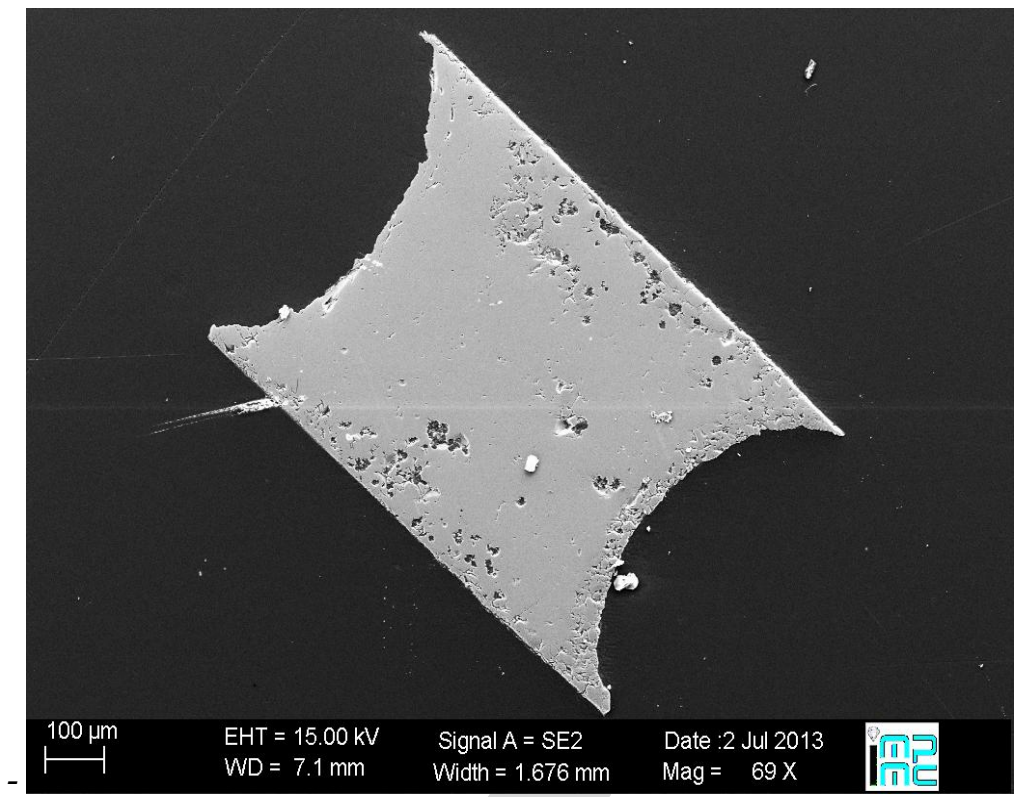

Figure 1a: SEM image of the glass quenched from 3.4 GPa recorded at IMPMC, CNRS, Paris showing the homogeneity of the quenched sample as well as the lack of large scale crystallization of the high-pressure recovered quenched sample. The $0.1 \times 0.5 \mathrm{~mm}^{2}$ EXAFS beam was centred in the middle of the capsule.

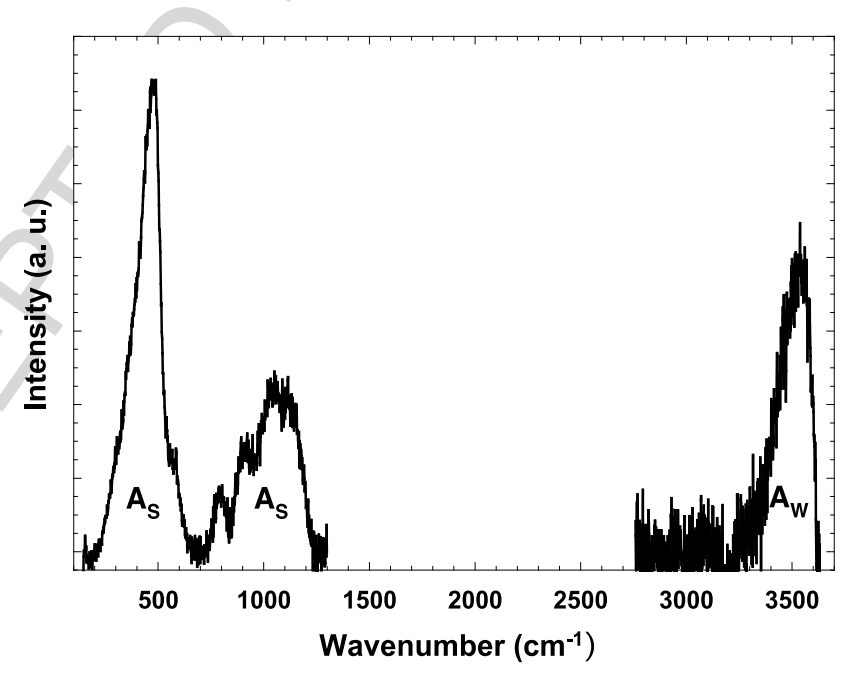

Figure 1b: Raman spectrum of the glass quenched from 3.4 GPa plotted after baseline subtraction. The water content was determined after calculating the ratio, $R w / s$, between the "silicate" region's area, $A_{s}$, and the "water" region's area, $A_{w}$, as $R_{w} / s=A_{w} / A_{s}$, then correlating it with the empirical calibration of Le Losq et al. (2010). 
Figures 2: Normalized X-ray absorption spectra $(a), k^{2}$-weighted $\chi(k)$ EXAFS oscillations $(b)$ and Fourier transforms $(c)$ for crystalline bromine model compounds at ambient conditions. The spectra have been shifted in the vertical direction for clarity. Red dashed lines are least-square fits performed using IFEFFIT. Contributions around the Br atom arising from the first neighbours are labelled. Peak positions are uncorrected from backscattering phase shift (c). The corrected interatomic distances are reported in Table 2. For reason of clarity the amplitude of the $k^{2}$-weighted $\chi(k)$ EXAFS oscillations and Fourier transforms of $\mathrm{NaBrO}_{3}$ and $\mathrm{KBrO}_{3}$ reference compounds have been divided by two.
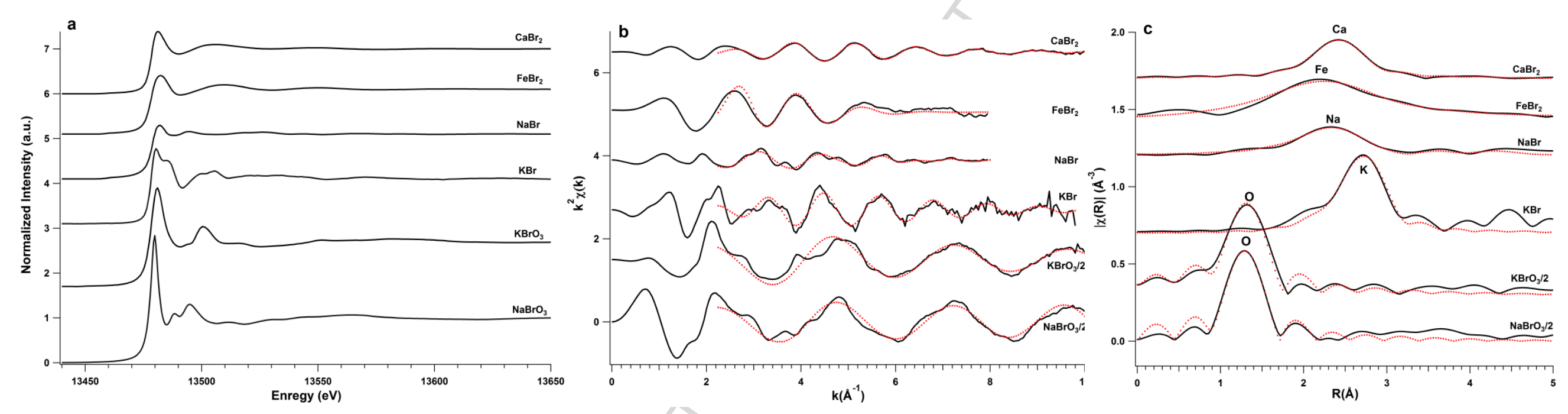


\section{ACCEPTED MANUSCRIPU}

Figures 3: Normalized X-ray absorption spectra $(a), k^{2}$-weighted $\chi(k)$ EXAFS oscillations $(b)$ and Fourier transforms $(c)$ for the starting glass at ambient pressure, the glasses quenched from high pressure $(Q)$ and the melts $(M)$ at the pressure indicated in GPa. Red dashed lines are least-square fits performed using IFEFFIT. Peak positions are uncorrected from backscattering phase shift (c). The corrected interatomic distances are reported in Table 3.
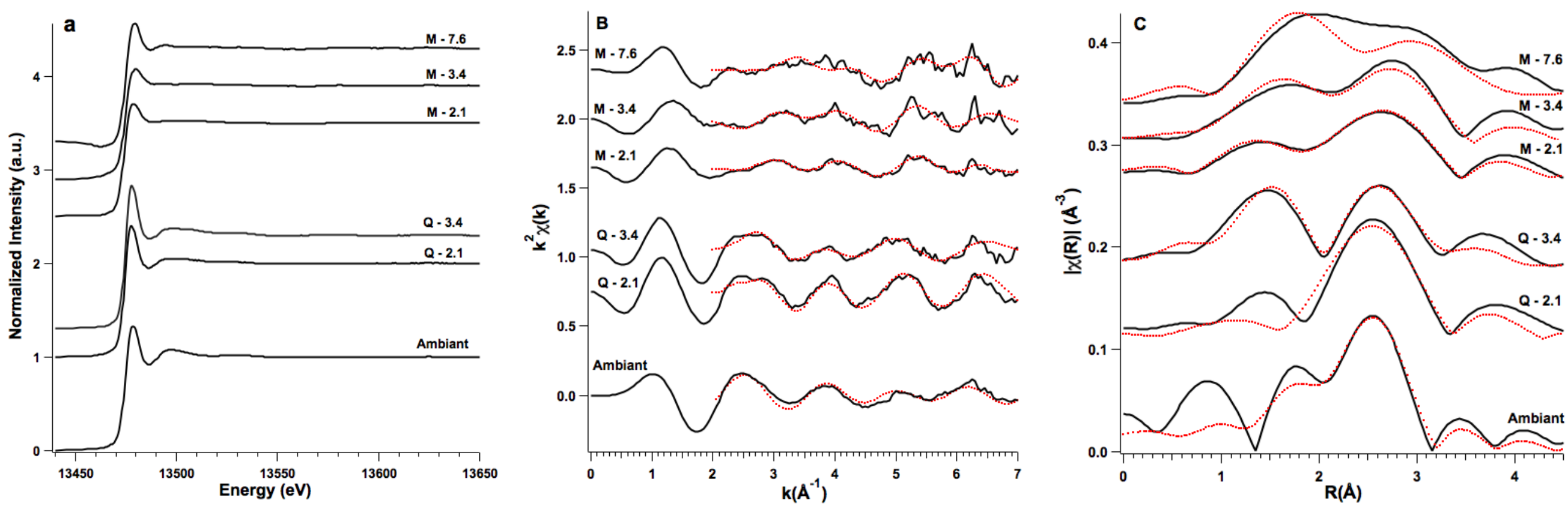
Figure 4: Schematic representation of the Br speciation in high-pressure silicate melts. The proposed model obtained from the EXAFS experiments shows a transition in $\mathrm{Br}$ speciation from a $\mathrm{Br}\left[\mathrm{Na}_{x}\left(\mathrm{H}_{2} \mathrm{O}\right)_{y}\right]$ complex at low pressure (parent glass) to a Br atom surrounded by an increasing number of Na ions with one or two oxygen atoms at $\mathrm{P} \geq 2 \mathrm{GPa}$. Colour code is the following: $\mathrm{Br}$ (large green), $\mathrm{Na}$ (large purple), $\mathrm{O}$ (light blue) and $\mathrm{H}$ (pink). The lines between the Na atoms are guides to the eyes.

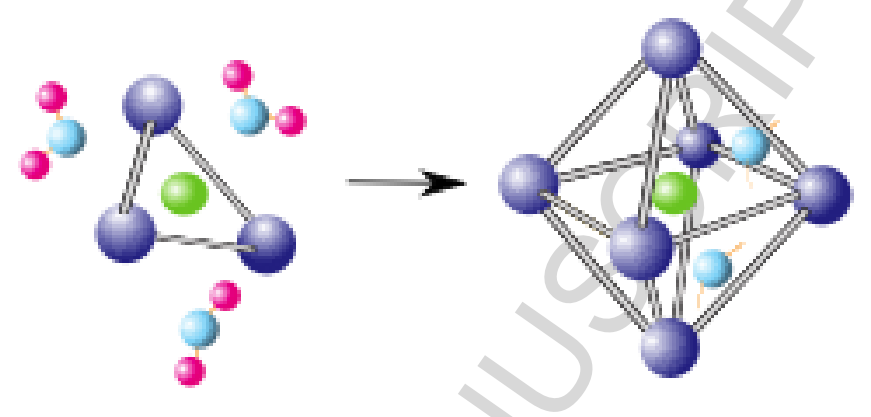


Figure 5: Evolution of (a) bromine coordination numbers $\left(N_{B r-O . H}, N_{B r-O}\right.$ and $\left.N_{B r-N a}\right)$ and $(b)$ distances ( $\mathrm{Br}-\mathrm{O} . . \mathrm{H}, \mathrm{Br}-\mathrm{O}$ and $\mathrm{Br}-\mathrm{Na}$ ) as a function of pressure for the melts (open symbols and dashed lines) and the glasses quenched from high pressure (plain symbols and line).
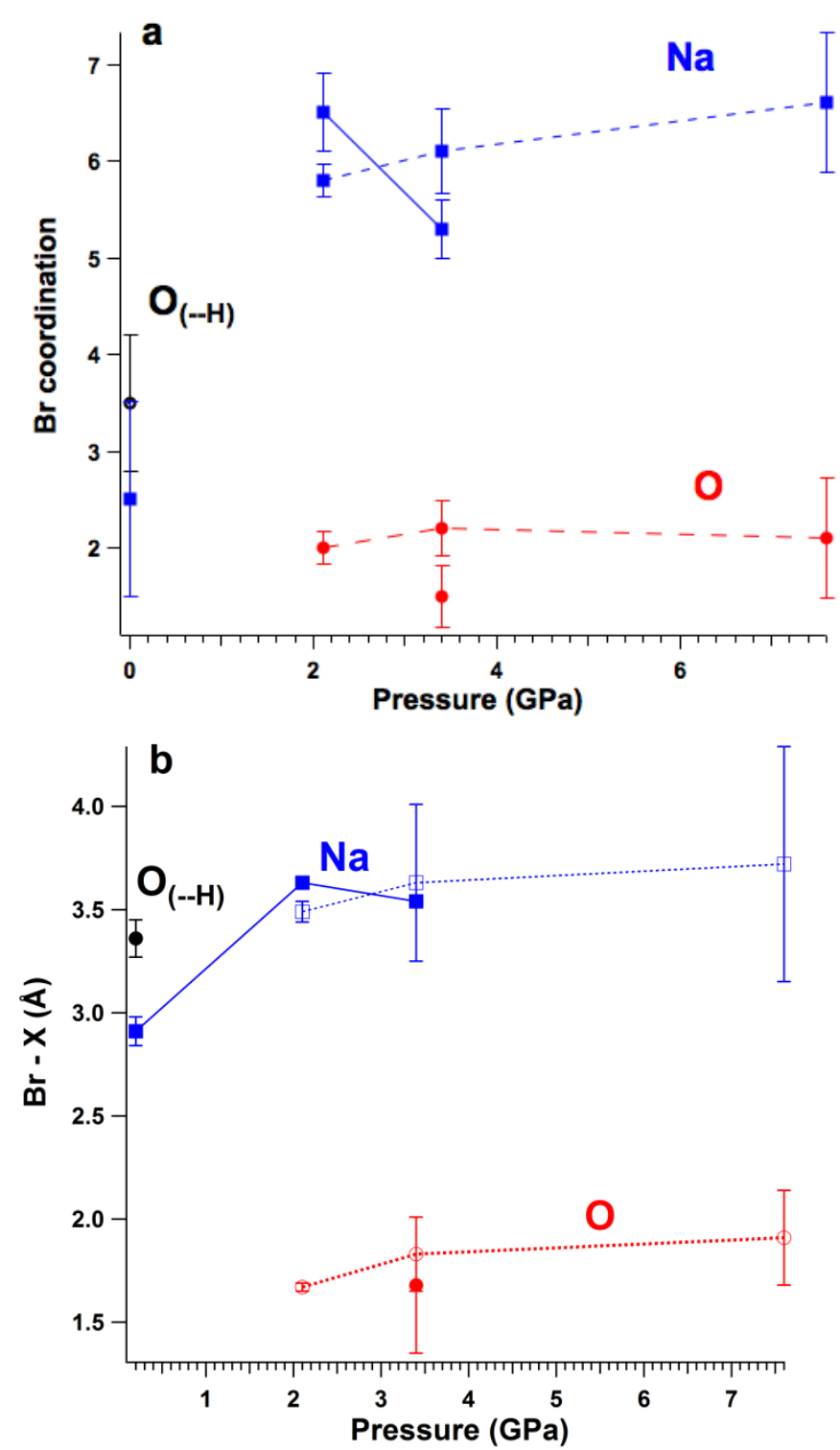


\section{Highlights}

- Br speciation has been investigated in hydrous silicate melts up to 7.6 GPa by EXAFS spectroscopy

- $\mathrm{Br}$ is surrounded by increasing number of $\mathrm{Na}$ cations (5.8 to 6.6), with an increasing $\mathrm{Br}-\mathrm{Na}$ distance (3.49 to $3.72 \AA$ )

- Two oxygens form the closest coordination shell around $\mathrm{Br}$ ions

- Br can be retained in the melt structure at relatively high pressure which supports the idea of its deep recycling

- Br could also be efficiently degassed with water at low pressures 